\title{
US Environmental Protection Agency
}

\section{Political pollution unabated}

\section{Washington}

CONGRESSIONAL investigators last week released documents suggesting that a White House official had sought to manipulate the awarding of hazardouswaste clean-up grants in order to help selected candidates in last November's elections. The documents add credence to earlier testimony by Environmental Protection Agency (EPA) officials before the investigations subcommittee of the House Energy and Commerce Committee that they had been ordered to speed up work on certain grants so that they could be announced before the election.

The new evidence also, for the first time, implicates the White House directly in the growing scandal at EPA. According to calendars turned over to the investigators, Rita Lavelle - the EPA official in charge of hazardous waste - met James Medas, a special assistant to the President for intergovernmental affairs, on 13 July last year. Notes taken at that meeting by Lavelle's assistant, Susan Baldyga, show that the discussion was devoted to a rundown of state governors' election campaign "races".

Baldyga's notes, headed "Jim Medas/go through the races", includes comments: "New Jersey - Keene (sic) help him all we can" and "New England/Bend over backwards/Snelling/Edward King'. Thomas Kean, the Republican governor of New Jersey, was reelected in a very close race against Democrat James Florio, a member of Congress. Richard Snelling is the Republican governor of Vermont, also reelected; Edward King, conservative Democrat, lost in his bid for reelection as governor of Massachusetts.

More revealing are several pages of notes found in Baldyga's office. These list candidates state-by-state and also contain clear references to hazardous waste sites. The notations "no political hay" and "no new sites" appear frequently on the list, as do indications of candidates selected to make "announcements". Another of Baldyga's notes, referring to the Tar Creek waste sites in Oklahoma (which EPA had listed as one of the 418 priority sites), bluntly states, "Status on Tar Creek/Political way to play Tar Creek". EPA awarded $\$ 435,000$ on July for cleaning up Tar Creek.

A check on hazardous-waste sites for which clean-up funds were authorized in the three months preceding the election shows that the largest number in any one state - 17 - was in New Jersey. New York was next with 8 . Both Lavelle and Baldyga were fired from EPA during the first shakeup at the agency last month.

Medas, in a statement released by the White House, said "At no time did I say, suggest or imply that EPA policies ought to be shaped to meet political considerations". The White House had earlier said that Lavelle and Medas discuss$0028-0836 / 83 / 130370-02 \$ 01.00$ ed only "political contacts they had in California". After Baldyga's notes were released, Medas admitted discussing some races but not waste sites, with Lavelle.

Meanwhile, in an effort to get the beleaguered agency swiftly back in action, President Reagan last week announced that William Ruckelshaus, the first EPA administrator, would replace Anne Burford as head of EPA. Ruckelshaus, who served under President Nixon in the early 1970s, was considered an environmental moderate. He was also acting director of the Federal Bureau of Investigation under Nixon and deputy attorney general until he resigned in 1973 in the "Saturday night massacre" when he refused to carry out President Nixon's orders to fire Watergate special prosecutor Archibald Cox.

Late last week, there were more shakeups at the agency. John Hernandez, the deputy EPA administrator who has served as acting administrator since the resignation of Mrs Burford, was asked to resign by President Reagan. Hernandez has himself been at the centre of controversy for allowing Dow Chemical Company to rewrite a report on dioxin contamination around a Dow plant. Also asked to resign were Robert Perry, EPA's general counsel, and John Todhunter, assistant administrator for pesticides and toxic substances. White House officials said this was to give Ruckelshaus a free hand in bringing in his own staff. Stephen Budiansky

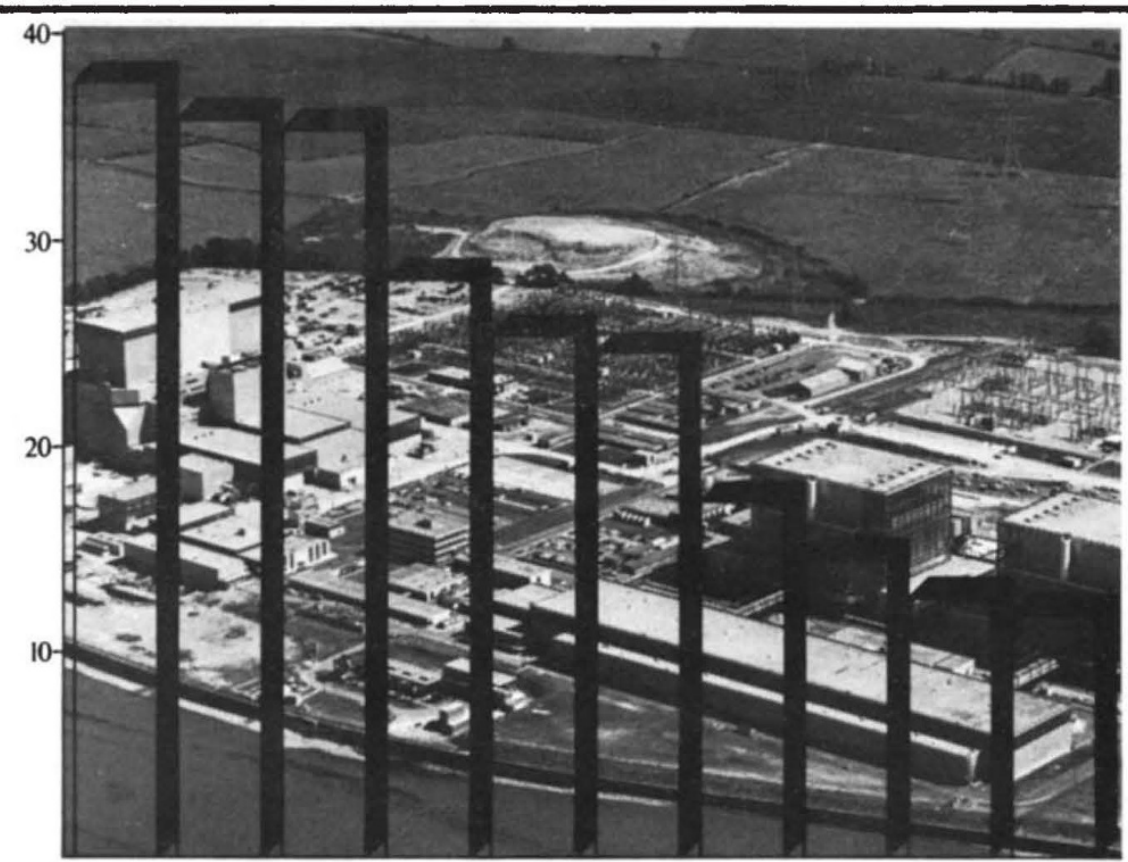

The 1981 world league table of nuclear power users in which countries are ranked according to the percentage of their electricity generated using nuclear power has been released by the International Atomic Energy Agency (IAEA). IAEA puts France as the top producer and Finland in second place. However, provisional figures for 1982 show this situation to be reversed, with Finland generating 40.3 per cent of its electricity through nuclear power and France generating 48.7 per cent.

\section{Third World science New centre}

\section{Bangalore}

SCIENCE and technology have an important play in promoting socio-economic growth in developing countries. That was one of the points made at the seventh NonAligned Summit (NAM) Conference of 101 Third World countries held recently in New Delhi. On the very first day, it was decided to create a centre for science and technology for non-aligned countries with its headquarters in New Delhi.

In her inaugural address to the conference, Mrs Indira Gandhi, the Indian Prime Minister, called for cooperation among the developing countries in the spheres of "agriculture, irrigation, plant genetics, public health, technical training and small industries". Pointing out the role of science in eradicating poverty, Mrs Gandhi observed that "at present 90 per cent of the world's research is not relevant to us because it is earmarked for the priorities of the technological leaders. Each developing country must therefore strengthen its domestic base in science and technology, and we should collectively devise more effective mechanisms for the pooling of our experience"'. She added: "Some people still consider concern for the environment an expensive and perhaps unnecessary luxury. But the preservation of the environment is an economic considerasince it is closely related to the depletion, restoration and increase of resources."

Radhakrishna Rao 